\title{
Inequality, Social Protests and Civil War
}

Fabio Andrés Díaz

\section{ABSTRACT}

The following article presents a series of hypotheses to analyze the possible transitions between protest and civil war and their relation to inequality. To do so, the article presents an analysis on the emergence of protests and its relation with the increase in inequality across the world. This increase in inequality can in fact lead to social unrest, instability and in some cases facilitate the emergence of future armed conflicts. Thus this scenario of increased inequality presents different possible trajectories: 1) protest generated by inequality can escalate into civil conflicts and civil war, or 2) protest generated by inequality can facilitate processes of participation and democratic consolidation. The possibility of either of these transitions taking place is defined by the structural conditions that define the interactions between protestors and authorities in particular settings.
Key words: Inequality, horizontal inequality, Vertical inequality, protest, civil wars.

\section{Inequidad, protestas sociales y guerra civil}

\section{RESUMEN}

A partir de una serie de hipótesis se estudian las posibles transiciones entre protestas y guerras civiles, y su relación con la existencia de inequidades en diferentes constituyentes. Se analiza la emergencia de una nueva ola de protestas, su relación con la existencia de inequidades y su aumento a nivel mundial. Este aumento puede, de hecho, favorecer la emergencia de conflictos sociales, inestabilidad política, y, en algunos casos, facilitar la emergencia de futuros conflictos armados. Este escenario de mayor inequidad presenta posibles trayectorias, de manera que las

* MA in Development Studies. Research Associate, Department of Political and International Studies Rhodes University \& Researcher International Institute of Social Studies, Erasmus University, Rotterdam (Netherlands). [diazpabon@iss.nl].

Recibido: 23 de marzo de 2017 / Modificado: 13 de julio de 2017 / Aceptado: 9 de agosto de 2017

Para citar este artículo:

Díaz, F. A. (2017). Inequality, Social Protests and Civil War. OAsıs, 26, 25-39.

Dor: https://doi.org/10.18601/16577558.n26.03 
protestas podrían escalar hacia conflictos y guerras civiles; o pueden convertirse en parte de procesos de participación y consolidación democrática. Sin embargo, la posibilidad de estas transiciones está definida por una serie de condiciones estructurales que son endémicas a cada país.

Palabras clave: inequidad, inequidad horizontal, inequidad vertical, protestas, guerra civil.

\section{INTRODUCTION}

Is inequality related to the increase of protests? Is it likely that inequality will drive an increase in armed conflicts in the future? This article attempts to answer these questions, reflecting on the increase of inequality of incomes and the existence of protests and civil wars.

The emergence of protests across the globe (since 2008) under different flags and agendas presents a phenomenon that requires further analysis. This is a symptom of social discontent, and could be interpreted as a symbol of dissatisfaction with the current political settlements in different countries. These tensions have been fuelled by the increase in inequality within countries (from the 1980's) and the loss of responsiveness from states. However, the tensions created by inequality and the pressures/limits to state responsiveness are not new, protest was central to the emergence of the modern nation state and democracy ${ }^{1}$. Thus the increase in protests should not necessarily be seen as something we should be afraid of, but rather as an opportunity to consolidate participation within different states and constituents.

This research departs from the assumption that protests and riots are a symptom of social discontent with existing social contracts (Dabla-Norris, Kochhar, Suphaphiphat, Ricka $\&$ Tsounta, 2015), and that protests are therefore central to the process of negotiation and renegotiation of different social contracts. It is in this context that the ebb of the welfare state and the increase in inequality submits states and their institutions to tensions (Hobsbawn, 2007 , p. 4). Thus the emergence of a new wave of protests in response increase of inequalities can be seen as a symptom of future conflicts (Hobsbawn, 2007, p. 42). However these tensions are not expressed uniformly; protests should not be equated to violence or civil war, rather we should consider what elements seem to drive the transformation from unrest to violence and armed conflict. Protest is protest, civil war is civil war, and although they can be related in wider socio-historical processes, they are not the same.

Thus the emergence of a new wave of protest that arise in contexts of high/increased inequality requires further analysis of the different possible scenarios that might emerge in response to such increased protest. The article argues that these protests present an unstable equilibrium, which may follow different trajectories (protest can escalate into civil

1 Although protests were informed by different inequalities, the demands that informed these protests related to the time and the space where they took place, so in the case of most European states these are related to the demands of proto-citizens of the emerging nations states in the middle ages. 
conflicts and civil war, or protest can facilitate processes of participation and democratic consolidation).

The article presents a general overview of trends in inequality across the globe. The article proceeds to reflect on the impact of inequality on the emergence of protests and the possibility of the emergence of civil conflicts or civil wars according to findings in the literature. Finally, the article discusses different hypotheses regarding the impact of rising inequalities on protests, and the possibility of future conflicts taking place.

\section{UP OR DOWN?}

Descriptions of trends in inequality are dominated by claims supported by empirical evidence; however these claims often speak of inequality without making explicit the nature of the inequality described (vertical or horizontal), or adequately specifying around what aspects of a society inequality is increasing or decreasing (provision of public services, income, savings, education, etc.). As such, in many cases inequality functions as a category more than a proper descriptor. Thus if we aim to provide clear explanations around what is happening with inequality we need to elaborate around what is becoming more (or less) unequal, and how this inequality is being measured.

Therefore, to assess if inequality is increasing or decreasing I argue that we need to clarify four different things: what is being measured (income, outcome, etc.), the unit of analysis used (nation, individuals, regions, etc.), the measurement indicator used (Gini,
Palma, etc.) and the time interval over which inequality is being measured.

Different sources claim that income inequality is increasing. Income inequality seems to have been increasing since the 1980's. The debate on the importance of income inequalities and its increase gained salience as an outcome of the 2008 financial crisis (Cingano, 2014, p. 8; Galbraith, 2012, p. 4).

Although literature on global inequality (of incomes) and globalization have argued that incomes at national levels should converge, meaning that inequality of incomes should stop diverging, the reality is that inequality of incomes has maintained the trend towards divergence (Milanovic, 2010, p. 104; Krugman \& Venables, 1995).

Inequality and poverty are related, but are not the same. Nevertheless, the picture that links income inequality and poverty at a worldwide level is more complex than expected. On the one hand extreme poverty has fallen globally by more than half from 52 per cent to 22 per cent between 1981 and 2008 (World Bank, 2012, p. 1). At the same time, on average, income inequalities within countries seem to have increased (Milanovic, 2010, p. 153). This points to complex and intricate dynamics within countries. Citizens are on average better off than before, however, when it comes to income inequality, the differences between those within societies are widening.

However, we should bear in mind that inequality is not necessarily bad per se. There is good and bad inequality, and the type of inequality is what matters. Inequality of opportunities speaks of inequality in access to 
opportunities and in the capacity of individuals within a society to achieve their goals given this inequality. This bad form of inequality is widely understood to be unfair, and is evident in a society where the state does not respond equitably to its citizens such that the access to or provision of public services is unequal - this inequality entrenches cliques; access to resources and real citizenry is afforded those who have more power or resources. Inequality of opportunity produces inequality of outcome; success in such societies is predestined by one's position in society.

By contrast, inequality of outcomes refers to the inequality in the achievement reached by individuals as a byproduct of their efforts and work; this inequality is the difference in achievement where citizens had access to the same opportunities. This good inequality is the driver of innovation, success and entrepreneurship.

Our understanding of inequality and its extent is limited by our access to information and quality data. As such, we would expect better quality data to inform our understanding what is happening with regard to different kinds of inequalities in more "developed" countries. In addition, we should bear in mind that the measurement of inequality is something fairly recent, with a history of less than a hundred years (Kuznets, 1955).

In general, most of the assertions made regarding inequality in the literature in recent years refer to international inequality (the inequalities between countries), in particular to international inequality of incomes (Piketty, 2015; Stiglitz, 2012; Cingano, 2014; Galbraith, 2012). Most current accounts of inequality make comparisons between groups of countries for which data is available (North America and OECD countries). For example, in most OECD countries the gap between the rich and the poor is at its highest level in 30 years, as illustrated by the fact that the richest $10 \%$ of the population earn 9.5 times the income of the poorest $10 \%$ of the population in OECD countries (Cingano, 2014, p. 6).

It is important to state that a general description of what is happening to global inequality might be inaccurate (Milanovic, 2010). As the indicators on inequality tend to aggregate varied and diverse contexts (e.g. SubSaharan Africa is compared with Northern Europe and India, etc.), any claim regarding what is happening to inequality at a global level is bound to rely on strong generalizations ${ }^{2}$. Thus, in order to make these assertions more precise, we need to consider what is happening with regard to within country inequalities and how this impacts comparisons. The world is a diverse space, and aggregate indicators may produce inaccurate information as they tend to mask, rather than reflect, this inherent diversity.

Aggregation may serve to produce 'averages' that mask difference over geographical areas, among population groups and over time. For example, the measurement of inequality

2 In addition to this, since quality data is not necessarily available everywhere, some measurements rely on questionable data. 
of incomes (measured through the Gini index) for OECD countries shows different aggregate dynamics for three different time intervals in the same geographical space (see Figure one). From the mid 1980's to mid-1990's income inequality increased; from the mid-1990's to late 2000's there was a slight reduction of income inequality, while when we compare the income inequality in the interval between the mid-1980's to late 2000's we find an increase in income inequality in OECD countries.

\section{Figure 1}

Trends in income inequality. Percentage point changes in the Gini coefficient on income

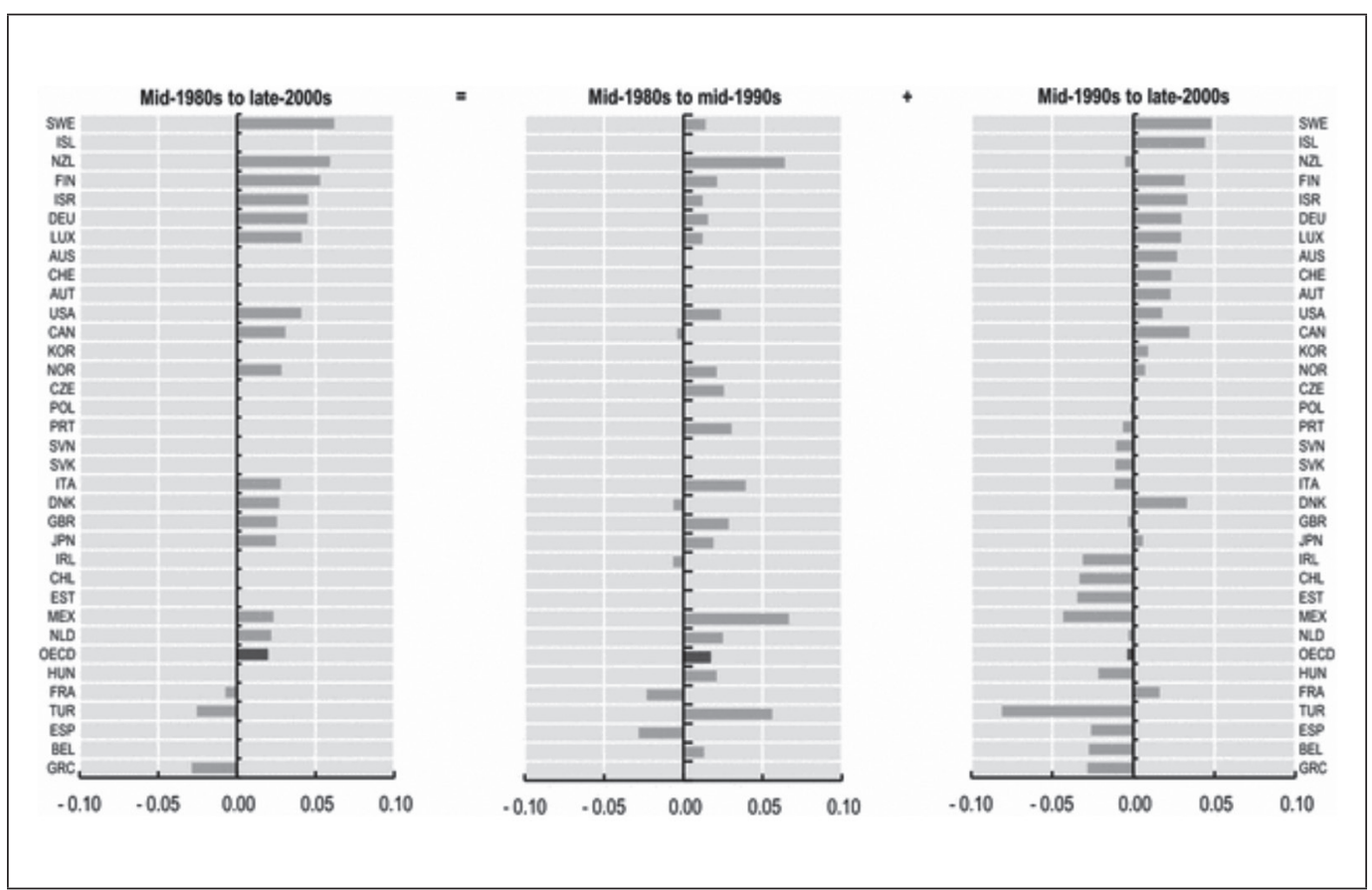

Source: OECD (2011).

It is important to note that the majority of the findings discussed in recent work on inequality use data from the 'western world' and pertain to these areas. Piketty shows that after a long downward trend, income inequality in "western" nations has increased in the last 30 years (1980 - 2010). This has been a byproduct of the decrease of direct taxation on income and 
inheritance (Milanovic, 2010, p. 10), and intensified by technological change ${ }^{3}$ (Economists for peace \& Security, 2016, p. 5).

The increase of income inequality, and the entrenchment of inequalities of opportunities further fuelled by the control of capital and technology by small groups of people present an important scenario to analyze, given that these forces can further inequality (Brynjolfsson \& McAfee, 2011; Milanovic, 2010, p. 107).

Income inequality thus has been representative of this process, and played an important role in the 2008 crisis, and the possible crises to come. This concern has been further fuelled by the apparent ability of money to bypass the capacity of states to regulate them (Piketty, 2015) due to its mobility.

While globalization is presented as the culprit of the rise of inequality ${ }^{4}$, we cannot overlook the fact that these changes in inequality are also ultimately the consequence of the national rules of the game agreed at a country level. Politics at a national level still matter (Stiglitz, 2012; Rodrik, 2012).
Evidence of continued increases in inequality of incomes became evident in the 1980 's when inequality began to increase in the advanced economies (Piketty, 2015, p. 20). This phenomenon of increases of inequality is further complicated by the fact that demographics have changed across the world across different countries 5 . The improvement in life expectancies brought about by the welfare state and improvements in health have affected intergenerational mobility as well (Lefranc, Pistolesi \& Trannoy, 2008, p. 514). As life expectancy has extended, disposable income has increased, fuelling further inequality trends: now old and wealthy citizens have more time to continue enjoying their rents while the tax on their inheritances that would have created some redistribution effects once they perish takes longer be effected, and has in any case also been reduced by lower taxation ${ }^{6}$. This means that the difference in incomes, savings and the like are more likely to be stretched out than grouped in the future. The seed of future protests.

\footnotetext{
3 Technological change has increased the return to skilled labour relative to unskilled labour, increasing income inequality

As capitalism at a global scale drives down wages, the role of multinational companies and hyper financialization is increased through financial liberalization and weak regulation; thus, there is the likelihood that income inequality is due to increase.

5 I have not described on this document the trends in income inequality in the 'non-advanced' world. Therefore for stating the hypotheses of the increase of income inequality and protests, I will resort to the evidence of oECD countries.

6 Surely there should be differences in regards to the impact and the extent of the changes in inequality (of incomes) in non-OECD countries; however given the absence of good quality data in some of these countries, it is hard to assess as part of a general assessment (one could undertake specific country analysis for this) how different are the mechanics of trends in inequality in these contexts.
} 


\section{Inequality and protest}

Research on the impact of inequality on protests has gained salience in recent years as a product of recent developments such as the occupy movements, and the financial crisis of 2008 (Galbraith, 2012). However, protests are not new phenomena (Tarrow, 2011). In fact, it can be claimed that protests play a constitutive role in the inception of the modern nation state (Tilly, 2006). What we will see is the possibility of protests related to the increase of inequality in different countries taking place.

Thus, when a group of citizens protest in relation to inequality, they protest with regard to a particular subject, policy or action related to inequality - be it inequality in educational provision, access to public services, or the levels of unemployment in a particular country. Thus, the existence of protests related to inequality can be thus understood in relation to the existence of inequalities with regards to the expectations and delivery of public policies (real, or perceived).

Governments' responses to inequality cannot assume that full equality would lead to there being no protests at all. The notions of equality and inequality have multiple dimensions; the possibility that any system and any social contract could avoid unacceptable inequalities in all dimensions is a chimera (Sen, 1992). However, what can be argued is that policy options should aim to reduce inequalities of opportunities, so that the existing inequalities in countries are those related to outcomes and achievement. This would involve limiting the impact of particular inequalities that entrench inequalities with re- gard to the provision of and access to public services and rights.

Understanding the impact of protests related to inequality and their link with statehood should allow us to consider how protests related to inequality have been related to processes of instability across the world. The revolutions in Russia, China and France were preceded by protests. The claims underpinning these protests were informed by the inequality between different constituents (Skocpol, 1979). When South Africans protested during and after Apartheid, their protests have been informed by the unequal treatment given to citizens by their government. When Sinhalese and Tamils protested before the emergence of the civil war in Sri Lanka, they did so in response to the unequal allocation of resources and benefits to citizens (Abeyratne, 2004). The protests and riots in Northern Ireland before the emergence of the civil war expressed a demand to belong to a society of equals (White, 1989, p. 36).

The recent increase in protests across the world under different banners therefore requires attention (Heidelberg Institute for International Conflict Research, 2015; DablaNorris, Kochhar, Suphaphiphat, Ricka \& Tsounta, 2015). These protests could signal an era of instability and tension. The claims that inequality can breed instability (Stiglitz, 2012 , p. 27), and in other cases that instability breeds inequality which bears instability (Cingano, 2014, p. 11), are valid and should be given attention.

The existence of extreme inequality has the potential to damage trust and social cohesion and the belief in the social contract and 
its institutions within a particular country and can lead to instability (Milanovic, 2010). It is in this context that income inequality, and the rise of other inequalities, has the potential to fuel the de-legitimization of the state structures, mobilizing opposition frustrated with the status quo (Cederman, Gleditsch \& Wucherpfenning, 2014).

When denunciations of the status quo are not responded to or acknowledged by the state, there is a higher likelihood that political instability will result (World Bank, 2012, p. 2). History reminds us that citizens denied of adequate forms of participation will protest and even revolt (Fukuyama, 2011, p. 32). Inequality is thus deeply related to protests. However, the existence of inequalities does not lead to one single possible outcome (protest); civil conflict and civil war is another possible outcome.

\section{Inequality and civil war}

The relationship between inequality and civil war is still contested; evidence can be found to support the link between inequality and conflict, and also to reject this relationship (Mancini, 2008, p. 2). Does this mean inequality does not matter for conflict? The absence of conclusive evidence does not necessarily mean we should disregard the findings and insights of academics who have found evidence supporting both claims. If we are to understand how inequality affects or does not affect the emergence of conflict, we need to determine under which conditions inequality can be related to civil war and civil conflict.

A preliminary illustration of the inconclusive nature of the balance of evidence on the relationship between inequality and conflict can be illustrated in the figure above (Figure 2). As we can see, several countries where inequality is salient (according to this particular index) - Brazil, The United States of America, and Chile - do not suffer/have not suffered from civil war in the last 70 years. However, other countries on the continent with similar levels of inequality have experienced or suffer from conflict within the same time period, for example Colombia, Nicaragua and Guatemala. As such, it seems that there is something more to conflict than just inequality per se.

This lack of a clear and consistent causal link between inequality and civil war calls into question the claims of the literature which asserts that inequality does make civil war more likely (Houle, 2015, p. 2). This connection remains unclear (Buhaug, Cederman \& Gleditsch, 2014, p. 418), as whether or not inequality translates into conflict depends on other factors, including the legitimacy of the state, its strength and the political conditions of a country (Cramer, 2003, p. 409). It might be the case that elements mediate between increases in inequality and the emergence of civil war: the strength of the social contract, the perception of citizens and the facility to mobilize citizens against the state and the capacity of the state to embrace dissent. 
Figure 2

Inequality in America in 2013 using the GINI index (on income) as a measure of inequality for each country ${ }^{7}$

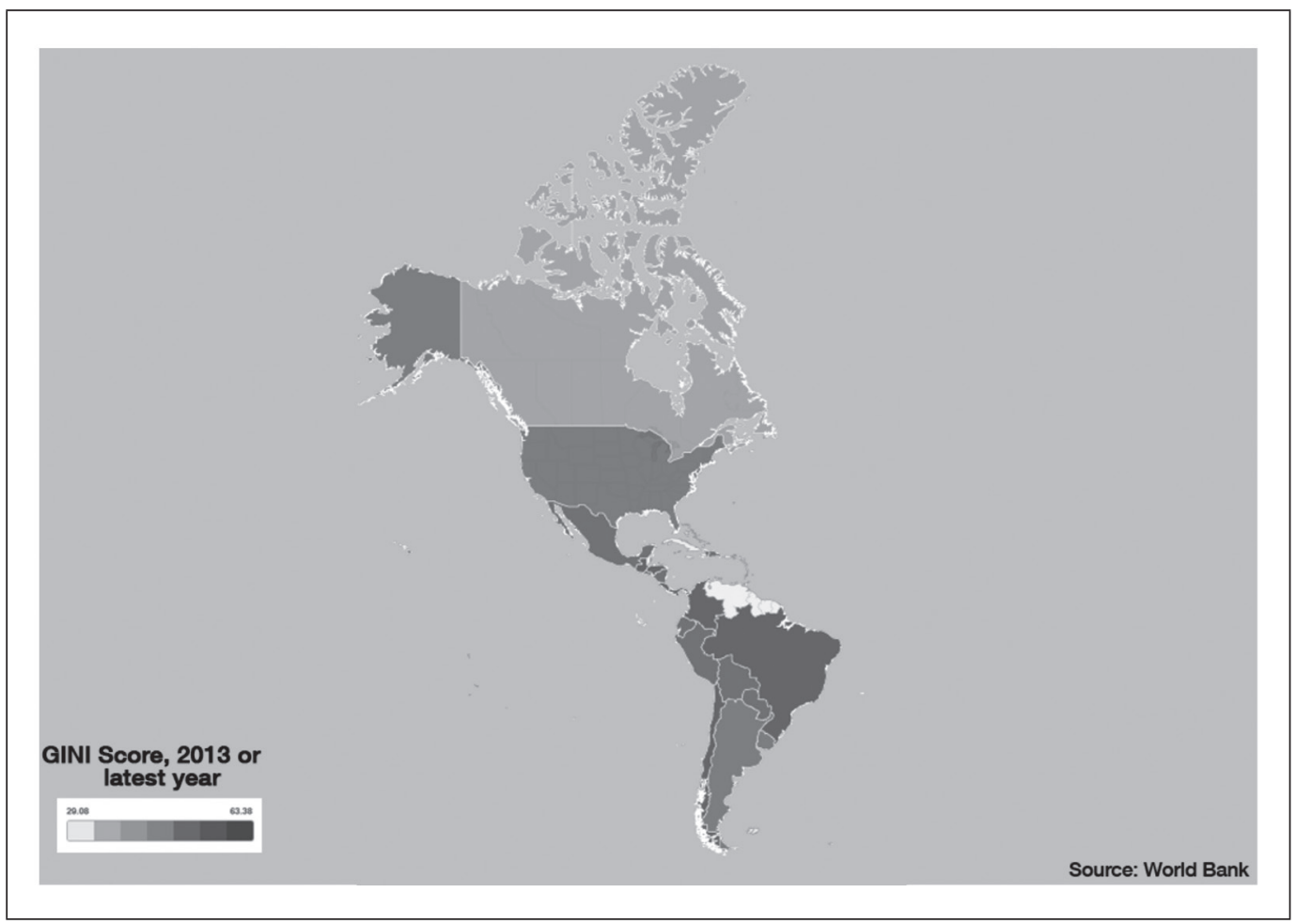

Source: World Economic Forum (2015).

The debate about the role of inequality in relation to the existence of civil war and protests involves many competing claims (Buhaug, Cederman \& Gleditsch, 2014; Dabla-Norris, Kochhar, Suphaphitat, Ricka \& Tsounta, 2015; Cramer, 2003; Tilly, 2003; Gurr, 2015).
However, these are better understood through differentiating these claims by the type of inequality being analysed: horizontal ${ }^{8}$, or vertical inequality ${ }^{9}$. It has been found that vertical inequality is not statistically related to the onset of civil wars (Collier \& Hoeffler, 2004;

7 The darker the color of a country, the more unequal the country is.

8 The inequalities between individuals belonging to different groups. For example, wealth inequality between black and white citizens of a country.

9 The inequality among individuals in a unit of analysis. For example wealth inequality in a country. 
Fearon \& Laitin, 2003), while horizontal inequality has been found statistically significant in describing the emergence of armed conflicts (Murshed \& Gates, 2005; Stewart, 2008; Østby, 2008 Cederman, Weidmann \& Gleditsch, 2011). However, it is accurate to state that prevalent vertical inequalities have the potential to destabilize the social contract, and this can be manifested in processes of contestation that could escalate into civil war (Murshed, 2009.

The research on horizontal inequalities offers an avenue that is better able to understand the nuances of inequalities and conflict, especially given its interest in assessing both how the differences between different constituencies (groups) within a country inform and relate to the emergence of civil conflict and civil war (Langer, Stewart \& Venugopal, 2012, p. 1), and when political and socio economic disparities (inequality of opportunities) increase the risk of civil war and civil conflict (and when they do not) (Buhaug, Cederman \& Gleditsch, 2014, p. 10).

Horizontal inequality facilitates mobilization towards conflict. This argument emerges from the observation that poverty regularly fosters citizens' participation in warfare. Inequality reduces the cost of hiring recruits; this makes the possibility of mounting a rebellion or recruiting soldiers easier (Houle, 2015 , p. 9). In addition it has been found that in societies where cultural or ethnic markers are salient, identity plays an important role reducing the costs of mobilization (not to be confused with the false claim that ethnicity makes war more likely) (Collier \& Hoeffler, 2004). Where groups are marginalized and suffer from inequality, the importance of boundaries between different entitlements is heightened, as compared to a society without ethnic markers. This magnifies the notion of relative deprivation and fosters the possibility of the emergence of conflict where deep horizontal inequalities are expressed (Buhaug, Cederman \& Gleditsch, 2014, p. 421).

However, the existence of salient inequalities does not imply the emergence of war. The emergence of civil war requires the sponsorship of an financier, or the presence of resources that could be looted; without this, the recruitment, financing and operation of an armed resistance are hampered. One could in fact expect that in the absence of financiers and of external funding, the emergence of civil war in highly unequal countries would be limited. In addition the strength of the armed forces must be taken into account; it is assumed that the bigger (or the stronger) the armed forces are, the less likely it is that a civil war might emerge. Finally, the role of institutions and the state's institutional framework for embracing or deterring escalation towards violence is essential - this involves how grievances are dealt with or ignored by the state and its apparatus, and how dissent is engaged within a society. The state and its institutions play a role in these processes, which contribute to the emergence of civil war (Cederman, Weidmann \& Gleditsch, 2011, p. 478). Thus it is common to observe repression, apathy or mere incompetence as the main responses of states in which civil war emerged following armed protests.

If we overlook the possible links between protests about inequality and civil war we might be ignoring a key element in what 
defines the emergence of a particular type of contestation in a given country. I argue that protests and civil war can be studied as related processes, as they belong to a continuum in the state and the wider processes of contestation taking place within it.

Civil wars, civil conflicts and protests speak to (of) the state in different ways, and identify the state as a point of contention. Civil wars challenge the state in order to reform a social contract and acquire rights, political participation, resources, independence or secession. This relates to the state and its institutions, structures and organization. On the other hand, protests are actions undertaken by citizens of a particular territory who demand reforms, recognition, or inclusiveness from public institutions ${ }^{10}$, appealing to the arbitration or intervention of the state. Protest aim to achieve structural changes - secession, policy change, regime change or the overthrowing of the current regime may be the goal. Civil war and protest may aim for similar objectives (a deep reorganization of the state and the social contract), but seem to operate with different repertoires.

Analyzing the common properties that protests and civil wars share (Shaheen, 2015, p. 6; Hegre, Nygård \& Ræder, 2017; Dudouet, 2013) should thus allow us to further understand their interaction, possible relationship with each other, and their relationship to the study of inequalities (horizontal).

\section{INEQUALITIES AND THE INSTABILITY AHEAD}

It is important to reflect on how inequality may affect the capacity of the nation states to conduct its affairs; in particular it is important to discuss how the existence of inequality affects the likelihood of protests and turmoil in the future.

The capacity of states to respond to certain inequalities (income) is limited, thus the capacity of the state to respond to the demands in regards to these inequalities will have to deal with structural issues that are beyond the full control of the state and will be limited. Thus states face a challenge regarding how to regain legitimacy in the face of their constituents, given the difficulties faced in implementing policies that transcend their borders and the flows of capital that are not bounded by nationhood.

Widespread dissemination of information about different countries and lifestyles will create greater demands for equality of opportunities from the state will likely lead to an increase in protests related to the increase of inequalities (income inequalities) as disaffected citizens protest against their governments' perceived failure to deliver the goods, services, protections and opportunities provided that were expected or assumed to be received as part of their social contract (Murshed, 2002).

\footnotetext{
10 Here I address protests that are directed towards government actors. Protests that challenge the behavior of private actors are not considered here, despite the fact that these protests might relate with the public sphere and the existing social contract in a particular state.
} 
In countries where social mechanisms reproduce and stabilize exploitation and inequality (Tilly, 2003a; Mosse, 2010, p. 1162) a decrease in confidence in the institutions and the state will likely lead to unrest (Stiglitz, 2012).

Given this I propose the following hypotheses around the possible impacts of increasing inequalities for the emergence of protests and civil war:

Rising horizontal inequality that is paired with the failure of the state to fulfill its functions can lead to protests and civil war (Murshed, 2009, p. 139). Even in the cases where this loss of welfare due to state failure is acknowledged by states, but where there are not enough resources to compensate citizens' losses caused by rising inequalities (institutions cannot implement the changes that improve the conditions of citizens sufficiently fast, or where legitimacy is frail), instability will prevail - creating a vicious circle of instability and weakness in institutions.

An increase in inequality in a context in which representation is limited or failing will lead to a decrease in legitimacy and an increase in perceived relative deprivation, risking the weakening of the regime and the emergence of civil war. This is particularly the case in weaker autocratic states where cliques have assumed control and the provision of public goods is limited (Tilly, 2003b, p. 37).

In democratic regimes that that are incapable of exerting collective controls over financial capital, information, media and scientific and technical knowledge (weak democracies), rising inequality will create tensions that might weaken state institutions, and in some cases lead to de-democratization and instability
(Tilly, 2003b, p. 42). In these contexts when inequality increases we can expect protests to emerge in the short term.

In strong states with strong repressive apparatus, the presence of salient inequalities or increasing inequalities will not likely to spur protests or conflict. This is because of the dissuasive effect of the state, the difficulty of mounting opposition against a strong opponent, and the capacity of the state to instill effective propaganda campaigns that minimize the sense of relative deprivation (Ostby, 2007, p. 7). If an increase in inequality does not affect the capacity of the state to enforce laws, property rights and contracts, their own social contract, and its capacity to raise revenues and provide public goods (McLoughlin, 2015, p. 139), one may expect autocratic states to be impervious to inequality.

In democratic societies there is the possibility that an increase in protests (as a result of increased inequalities) will strengthen the state. Where democratic governments offer protection and create systems of extraction and allocation of resources that respond to popular demands for redistribution to address increasing inequalities, these might present collective benefits or the redistribution of resources in favor of those affected by various inequalities (Tilly, 2003b, p. 38), which can constitute a reassertion of their social contract. However, this is more likely to occur in strong states that are in the position to counter grievances due to having the resources to counterbalance the sense of deprivation (Bethke \& Bussmann, 2011, p. 2).

Inequality is connected to the social contract, and the nation state. The state will con- 
tinue to exist as a space in which inequalities are contested and where future tensions will put the capacity of the state to embrace dissent to the test. However the growing gap between the political and economic systems and the inequalities this separation creates will set the stage for the new challenges to be faced by nation states (Stiglitz, 2012, p. XXXVIII). These challenges and tensions will be heightened by the pressures of a globalized world on governments, citizens and their social compacts. These might in fact mark the beginning of a new era of global turmoil.

\section{REFERENCES}

Abeyratne, S. (2004). Economic roots of political conflict: The case of Sri Lanka. The World Economy, 1295-1314.

Bethke, F. \& Bussmann, M. (2011). Domestic mass unrest and state capacity. In Annual Meeting of the European Political Science Association (pp. 16-18). Dublin: European Political Science Association.

Brynjolfsson, E. \& McAfee, A. (2011). Race against the machine. Lexington, MA: Digital Frontier.

Buhaug, H., Cederman, L. \& Gleditsch, K. (2014). Square pegs in round holes: Inequalities, grievances, and civil war. International Studies Quarterly, 418-431.

Cederman, L., Gleditsch, K. \& Wucherpfenning, J. (2014). Explaining the Decline of Ethnic Conflict: Was Gurr Right and For the Right Reasons? Retrieved from http://www.observatoriodetierras.org/ wp-content/uploads/2014/11/EXPLAININGTHE-DECLINE-OF-ETHNIC-CONFLICTCEDERMAN-Y-OTORS.pdf

Cederman, L., Weidmann, N. \& Bormann, N. (2015). Triangulating horizontal inequality Toward im- proved conflict analysis. Journal of Peace Research, 806-821.

Cederman, L., Weidmann, N. \& Gleditsch, K. (2011). Horizontal inequalities and ethnonationalist civil war: A global comparison. American Political Science Review, 478-495.

Cingano, F. (2014). Trends in income inequality and its impact on economic growth. Retrieved from http:// www.oecd-ilibrary.org/social-issues-migrationhealth/trends-in-income-inequality-and-its-impact-on-economic-growth_5jxrjncwxv6j-en

Collier, P. \& Hoeffler, A. (2004). Greed and grievance in civil war. Oxford economic papers, 563-595.

Cramer, C. (2003). Does inequality cause conflict? Journal of International Development, 397-412.

Cunningham, D. \& Lemke, D. (2014). Beyond civil war: A quantitative examination of causes of violence within countries. Civil Wars, 328-345.

Dabla-Norris, E., Kochhar, K., Suphaphiphat, N., Ricka, F. \& Tsounta, E. (2015). Causes and consequences of income inequality: a global perspective. International Monetary Fund.

Della Porta, D. \& Diani, M. (2009). Social movements: An introduction. New York: John Wiley \& Sons.

Dudouet, V. R. (2013). Conflict Transformation Through Nonviolent Resistance. Conflict transformation: Essays on methods of nonviolence, 9 .

Economists for peace \& Security (2016). The Newsletter of Economists for peace \& Security. EPS quarterly, 16.Fearon, J. D., \& Laitin, D. D. (2003). Ethnicity, insurgency, and civil war. American political science review, 97(1), 75-90.

Fukuyama, F. (2011). Dealing with inequality. Journal of Democracy, 79-89.

Galbraith, J. (2012). Inequality and instability: A study of the world economy just before the great crisis. Oxford: Oxford University Press.

Gurr, T. (2015). Why men rebel. New York: Routledge. 
Hegre, H., Nygård, H. M., \& Ræder, R. F. (2017). Evaluating the scope and intensity of the conflict trap: A dynamic simulation approach. Journal of Peace Research, 54(2), 243-261.

Heildelberg Institute for International Conflict Research (2015). Conflict Barometer 2014. Heidelberg: Heilderber Institute for International Conflict Research.

Houle, C. (2015). Inequality, Coup-Proofing and Civil Wars. Retrieved from https://christianhoule.files. wordpress.com/2014/06/houle-inequality-coupproofing-and-civil-wars1.pdf

Krugman, P. y Venables, A. (1995). Globalization and the Inequality of Nations. National Bureau of Economic Research Working Papers, 5098, pp. 1-45.

Kuznets, S. (1955). Economic growth and income inequality. The American economic review, 1-28.

Langer, A., Stewart, F. \& Venugopal, R. (2012). Horizontal Inequalities and Post-Conflict Development. London: Palgrave Macmillan UK.

Lefranc, A., Pistolesi, N. \& Trannoy, A. (2008). Inequality of opportunities vs. inequality of outcomes: Are Western societies all alike? Review of income and wealth, 513-546.

Mancini, L. (2008). Horizontal inequality and communal violence: Evidence from Indonesian districts. In Stewart, F. Horizontal Inequalities and Conflict (pp. 106-135). London: Palgrave Macmillan UK.

McLoughlin, C. (2015). When Does Service Delivery Improve the Legitimacy of a Fragile or ConflictAffected State? Governance, 341-356.

Milanovic, B. (2010). The Haves and the Have-Nots: A Brief and Idiosyncratic History of Global Inequality. Basic Books.

Mosse, D. (2010). A relational approach to durable poverty, inequality and power. The journal of development studies, 1156-1178.
Murshed, M. (2002). Conflict, civil war and underdevelopment: an introduction. Journal of Peace Research, 387-393.

Murshed, M. (2009). The Social Contract and Lasting Peace. In Murshed, M. Explaining Civil War: A Rational Choice Approach (p. 256). London: Elgar.

OECD (2011). OECD Factbook 2011-2012: Economic, Environmental and Social Statistics. Retrieved from http://www.oecd-ilibrary.org/ sites/factbook-2011-en/03/05/01/03-05-01-g1. html?itemId=/content/chapter/factbook-2011$31-$ en\%20\&_csp_=90b604a83c7b3733189d8 e3237d9a1fd

Østby, G. (2008). Inequalities, the political environment and civil conflict: Evidence from 55 developing countries. In Horizontal Inequalities and Conflict (pp. 136-159). Palgrave Macmillan UK.

Piketty, T. (2015). The economics of inequality. Boston: Harvard University Press.

Rodrik, D. (2012). The globalization Paradox. Why global markets, states and democracy can't coexist. Oxford: Oxford University Press.

Sen, A. (1992). Inequality reexamined. Clarendon Press. Skocpol, T. (1979). States and social revolutions: A comparative analysis of France, Russia and China. Cambridge: Cambridge University Press.

Stiglitz, J. (2012). The price of inequality: How today's divided society endangers our future. New York: W. W. Norton \& Company.

Tarrow, S. G. (2011). Power in movement: Social movements and contentious politics. Cambridge: Cambridge University Press.

Tilly, C. (2003a). Changing forms of inequality. Sociological Theory, 31-36.

Tilly, C. (2003b). Inequality, democratization, and de-democratization. Sociological theory, 37-43. 
Tilly, C. (2006). Regimes and Repertoires (1st ed.). Chicago: University of Chicago Press.

White, R. (1989). From peaceful protest to guerrilla war: Micromobilization of the Provisional Irish Republican Army. American Journal of Sociology, 1277-1302.

World Bank (2012). Introduction to the inequality in Focus series. Retrieved from Ihttp://documents.world- bank.org/curated/en/445221468163745476/ pdf/799210BRI0Ineq0Box0379795B00PUB LIC0.pdf

World Economic Forum (2015). Agenda. Retrieved from https://agenda.weforum.org/wp-content/ uploads/2015/11/1511B11-americas-inequalitynorth-america-south-america-map.png 